\title{
Evolución imagenológica del aneurisma micótico ilíaco
}

\author{
Image evolution of an iliac mycotic aneurysm
}

Sandra Osorio V. ${ }^{1}$, Cristián Arriagada G. ${ }^{1}$, María José Villarroel F. ${ }^{2}$, María Ignacia Villablanca R. ${ }^{1}$ y Roberto Díaz H. ${ }^{2}$

Hombre de 56 años con antecedente de alcoholismo y tabaquismo. Consulta por dolor abdominal, sensación febril, baja de peso.

Examen físico: destaca masa abdominal pulsátil, febril $38,3^{\circ} \mathrm{C}$.

Exámenes de laboratorio: PCR 68, recuento de blancos 18.000, iniciándose antibióticos.

Imágenes: Angiotac pesquisó dilatación de la arteria ilíaca común izquierda con saco pseudoaneurismático de 2,4 x 2,4 cm rodeado de colección con burbujas de aire de $10 \mathrm{cc}$ (Figura 1).

Se realiza segundo angioTAC a las $48 \mathrm{~h}$, donde se comprueba un crecimiento de imagen de pseudoaneurisma con una colección de 18,6 cc (Figura 2).
Se realizó exclusión del aneurisma mediante un abordaje abdominal y ligadura de aorta infrarenal y a nivel de ilíacas comunes, posterior bypass axilobifemoral.

Cultivos: Salmonella enteridis (terapia antibiótica ceftriaxona).

Los aneurismas micóticos corresponden del 0,1 al $1,8 \%$ de los aneurismas, con una alta morbimortalidad. Su progresión es rápida, debido a la destrucción de la pared arterial por la proliferación bacteriana, en nuestro caso con un aumento de su tamaño de $85 \%$ en 48 h. Su tratamiento clásico implica resección del segmento arterial afectado, debridación del tejido subyacente, revascularización y tratamiento antibiótico como lo realizado en nuestro caso.

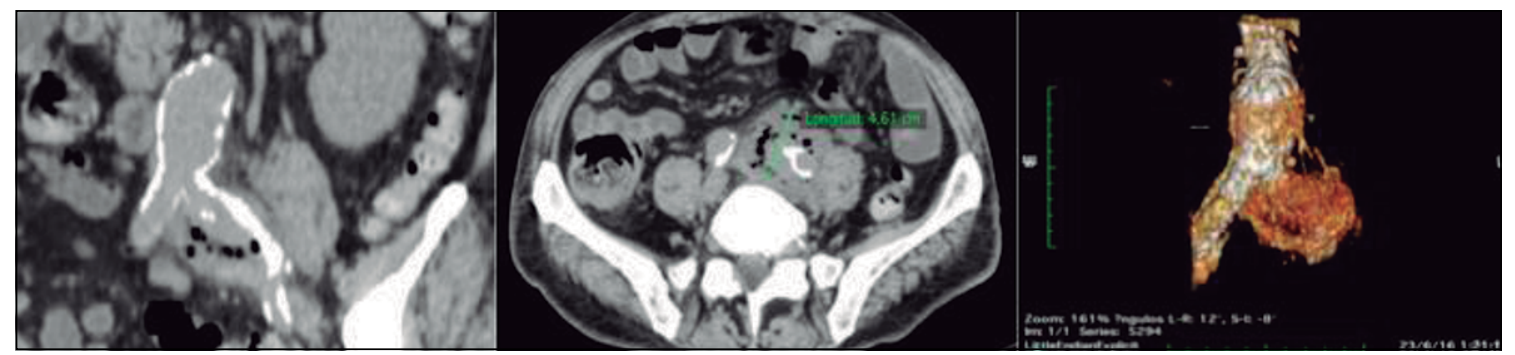

Figura 1. AngioTAC de ingreso.

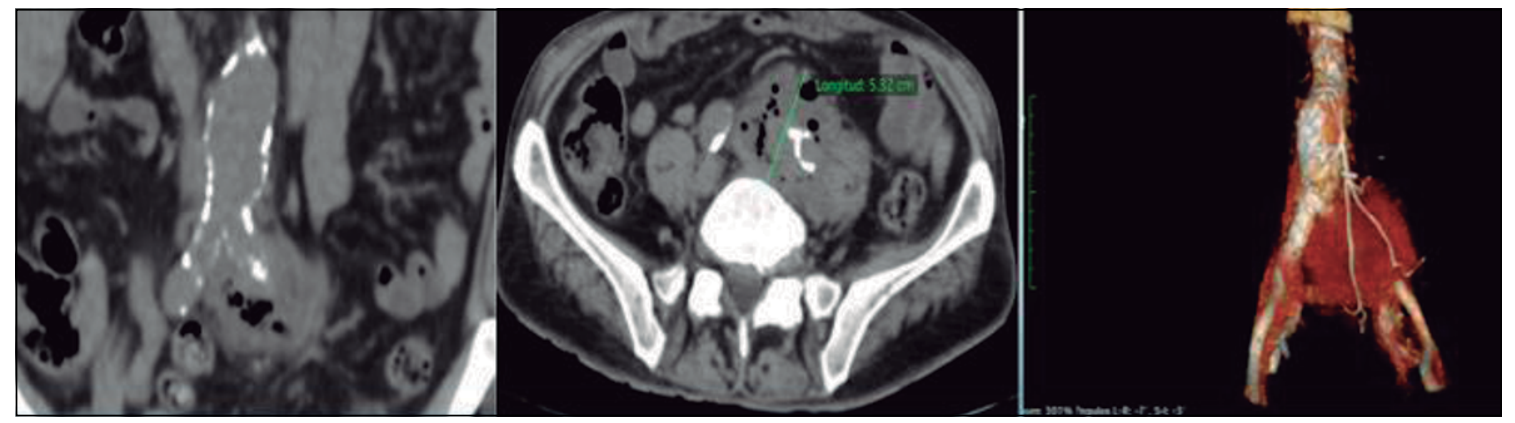

Figura 2. AngioTAC $48 \mathrm{~h}$. 


\section{Responsabilidades éticas}

Protección de personas y animales. Los autores declaran que para esta investigación no se han realizado experimentos en seres humanos ni en animales.

Confidencialidad de los datos. Los autores declaran que han seguido los protocolos de su centro de trabajo sobre la publicación de datos de pacientes.

Derecho a la privacidad y consentimiento in- formado. Los autores han obtenido el consentimiento informado de los pacientes y/o sujetos referidos en el artículo. Este documento obra en poder del autor de correspondencia.

\section{Financiación} ción.

El presente trabajo no posee fuente de financia-

\section{Referencias}

1. Jiménez C, Valencia A, Jaramillo $\mathrm{C}$, Correa J. Aneurisma aórtico por Salmonella. Rev Colomb Cir. 2011;26:214-21.
2. Muller BT, Wegener OR, Grabitz K, Pillny M, Thomas L, Sandmann W. Mycotic aneurysms of the thoracic and abdominal aorta and iliac arteries: Experience with anatomic and extra- anatomic repair in 33 cases. J Vasc Surg. 2001; 33:106-13.

3. León LR Jr, Mills JL Sr. Diagnosis and management of aortic mycotic aneurysms. Vascular and Endovascular Surgery 2010;44:5-13. 